\title{
Research of Torque Teno Virus (TTV) in Serum and Total Blood of Brazilian Non-Human Primates and in Chicken Plasma (Gallus gallus domesticus) by the PCR N22 Region
}

\author{
Investigación de Torque Teno Virus (TTV) en Suero y Sangre de Primates No Humanos \\ Brasileños y en Plasma de Pollo (Gallus gallus domesticus) por PCR en la Región N22 \\ *,***atroxo, M. H. B.; ${ }^{* * *}$ Nishiya, A.; ${ }^{* * *}$ Sabino, E.; ${ }^{* * * * *}$ Teixeira, P. S.; \\ ${ }^{* * * * * *}$ Petrella, S.; ${ }^{* * * * * *}$ Milanelo, L.; ${ }^{* * * * * * *}$ Vieira, J.C.F. \& ${ }^{* *}$ Diaz, R. S.
}

CATROXO, M.H.B.; NISHIYA, A.; SABINO, E. ; TEIXEIRA, P.S.; PETRELLA, S.; MILANELO, L.; VIEIRA, J.C.F.; DIAZ, R.S. Research of Torque teno virus (TTV) in serum and total blood of non-human primates and in chicken plasm (Gallus gallus domesticus) by the PCR-N22 region. Int. J. Morphol., 26(2):377-384, 2008.

SUMMARY: Torque teno virus (TTV) is a recently discovered DNA virus that was originally isolated from a Japanese patient (initials, TT) with post-transfusion hepatitis of unknown aetiology. TTV is an circular DNA virus classified recently together with related Torque teno minivirus, into a new genus called Anellovirus. Infection TTV has been detected in a range of non-human primates as well as domestic animals. The purpose of this study was to search TTV in the serum and total blood of Brazilian monkeys and in plasma of domestic chickens by seminested PCR of coding region (N22), followed by a genomic sequence and phylogenetic analysis. No serum sample was amplified. TTV DNA was detected in total blood from $3(4 \%)$ out of 75 brown-capuchin (Cebus apella) and from 1 (25\%) out of 4 golden-headed lion-tamarin (Leontopithecus chrysomelas). Phylogenetic analysis revealed that one sample showed similarity with one sequence of the cotton top tamarin (Saguinus oedipus) (So-TTV2) and with one of the douroucoulis (Aotes trivirgatus) (At-TTV3). Two samples showed similarity with a human Torque Teno Mini Virus (TLMV). The other sample clustered with one sequence of the chimpanzee (Pt-TTV6) and with the human TTV strain TA278. The plasma chicken samples tested were all negative. The amino acid sequences reported in this study are the first obtained in Brazil from total blood of non-human primates naturally infected by TTV.

KEY WORDS: Torque teno virus; Non-humans primates; Coding region; Amino acid sequencing.

\section{INTRODUCTION}

Torque Teno virus (TTV) is a recently discovered DNA virus that was originally isolated from a Japanese patient (initials, TT) with post-transfusion hepatitis of unknown aetiology (Nishizawa et al., 1997). Since discovery of TTV, studies have been published describing the prevalence of TTV infection in people with acute or chronic hepatitis as well as in blood donors and drug users and also in health persons (Biagini, 1998; Mac Donald et al., 1999). TTV is an unenveloped, single-stranded, and circular DNA virus with 30-32 nm of diameter (Miyata et al., 1999; Mushahwar et al., 1999; Itoh et al., 2000), classified recently together with the related Torque Teno Minivirus, into a new genus called Anellovirus (Biagini et al., 2005).

TTV is transmitted parenterally by transfusion (Okamoto et al., 1999), by enteric transmission demonstrated experimentally in chimpanzees (Luo \& Zhang, 2001; Tawara et al., 2000), and by vertical transmission (Saback et al.,1999). Also has been detected in saliva, on throat swabs, semen, tears, breast milk, hair, skin and raw (Saback et al.; Goto et al., 2000; Inami et al., 2000; Osiowy \& Sauder, 2000; Al-Moslih et al., 2007). Infection TTV has been detected in

\footnotetext{
Laboratory of Electron Microscopy, Institute Biological of São Paulo, Brazil.

** Laboratory of Retrovirology, Federal University of São Paulo-UNIFESP, Brazil.

*** Fundação Pro-Blood Homecenter of São Paulo, Brazil.

***** Institute of Biomedical Sciences, University of São Paulo, Brazil.

******** Institute Adolfo Lutz, São Paulo, Brazil.

${ }^{* * * * * * * *}$ Ecological Park of Tietê, São Paulo, Brazil.

${ }^{* * * * * * * *}$ Department of Surgical Techniques, Federal University of São Paulo-UNIFESP, Brazil.
} 
CATROXO, M.H.B.; NISHIYA, A.; SABINO, E. ; TEIXEIRA, P.S.; PETRELLA, S.; MILANELO, L.; VIEIRA, J.C.F.; DIAZ, R.S. Research of Torque teno virus (TTV) in serum and total blood of non-human primates and in chicken plasm (Gallus gallus domesticus) by the PCR-N22 region. Int. J. Morphol., 26(2):377-384, 2008.

a range of non-human primates (Leary et al., 1999; Verschoor et al., 1999; Abe et al., 2000; Cong et al., 2000; Okamoto et al., 2000a,b; Noppornpanth et al., 2001; Thom et al., 2003; Barnet et al., 2004; Pujol et al., 2005) as well as domestic animals, such as dogs, cats, swines, bovines, chickens, ovines, tupaias (thee shrews), wild boar (Sus scrofa) and camels (Leary et al.; Okamoto et al., 2001a; 2002; Mc Keown et al., 2004; Bigarré et al., 2005; Niel et al., 2005; Martelli et al., 2006; Martinez et al., 2006; Al-Moslih et al.).

Study of experimental transmission points out that the chimpanzees are susceptible to TTV infection and that can be cross infected with human (Mushahwar et al.; Okamoto et al., 2000a, b).

TTV genome includes two regions: a coding region (N22) and an untranslated region (UTR). The UTR is located at nt 3075-3853 and nt 1-352 occupying approximately 30\% of the genome (Okamoto et al., 1999; Ukita et al., 2000). Coding region consist of 6 ORFs with open reading frames (ORF1-ORF6) (Yokoyama et al., 2002). The N22 amplifies a fragment in open reading frame 1 (ORF1) and represents approximately $220 \mathrm{nts}$ of a genome that usually encompasses more than $3800 \mathrm{nts}$ (Miyata et al.; Mushahwar et al.). Consequently, almost every phylogenetic analysis of TTV is focused on this genomic region (Lemey et al., 2002).

The significant diversity of the TTV genome allows for its classification into more than 40 genotypes which cluster in five clearly distinct phylogenetic groups that are designated 1 to 5 (Okamoto \& Mayumi, 2001; Hino, 2002; Peng et al., 2002; Biagini et al.).

Other members of this virus family (SANBAM, YONBAN, TLMV (Torque teno Minivirus), SENV (SEN virus) and PMV (PM virus), presenting some genomic divergences have been related (Cong et al.; Hallet et al., 2000; Khudyakov et al., 2000; Takahashi et al., 2000b; DinizMendes et al., 2004).

The purpose of this study was to search TTV in the serum and blood of Brazilian monkeys and plasma of domestic chickens (Gallus gallus domesticus) by PCR of coding region (N22), followed by a genomic sequence and phylogenetic analysis.

\section{MATERIAL AND METHOD}

Animals: Were collected from August, 2000 to February, 2001, 90 serum samples and 70 total blood samples from various non-human primates, both sexes, including 26
Callithrix jacchus, 3 Callithrix kulii, 4 Leontopitecus crysomelas, 75 Cebus apella, 19 Callithrix penicilata, 2 Callithrix sp, 5 Alouata caraya, 5 Alouata fusca, 1 Saguinus m. niger, 1 Callithrix humeralifer, 3 Callithrix geoffroyi, 1 Aotus trivirgatus, 1 Calimico goeldi, 3 Saguinus m. midas, 1 Lagothrix lagotricha, 1 Erytrocebus pata, 2 Ateles $b$. marginatus, 1 Ateles peniscus, 4 Saimiri sciureus, 1 Saimiri fuscicollis, 1 Leontopitecus chrysopygus. These species are usually found in the Amazon Forest and Atlantic Rainforest (Mata Atlantica), in Brazil. These animals came from donations or rescues and were apprehended and sent to several ecological and Zoological Parks in São Paulo, Brazil where they were maintained in captivity. A total of 117 samples of chicken plasma (Gallus gallus domesticus) of the following lineages: white, brown leghorn and hens of yard, of both sexes from different poultry farms in the State of São Paulo, SP, Brazil, were collected from May to September 2001. Samples were kept at $-80^{\circ} \mathrm{C}$ until testing.

Extraction of nucleic acids and amplification by PCR: Blood DNA was extracted using a DNA Extraction Kit (Qiagen) from $100 \mu \mathrm{l}$ total blood. DNA was resuspended in $100 \mu \mathrm{l}$ buffer. Serum DNA $(50 \mu \mathrm{l})$ was mixed with $100 \mu \mathrm{l}$ Dnazol and $3 \mu \mathrm{l}$ Dextran T500 $(1 \mathrm{mg} / \mu \mathrm{l})$. The DNA was precipitated with isopropanol and resuspended in $25 \mu \mathrm{l}$ distilled water.

Heminested N22 PCR: In the first round, outer primers NG059 and NG063 (sequences 5' ACA GAC AGA GGA GGG AAC ATC - 3' and 5' - CTG GCA TTT TAG CAT TTC CAA AGTT - 3') were used.

PCR was carried out in $50 \mu \mathrm{l}$ volume, using $5 \mu \mathrm{l}$ of DNA, 10 pmol of NG059 and NG063 primers, $1.5 \mathrm{mM}$ $\mathrm{MgCl} 2$ and $5 \mathrm{U}$ Taq polymerase. In the second round, semiinner primer NG061 (sequence 5' - GGC AAG ATG YTR TGG ATA GAC TGG - 3') and the outer primer NG063 were used. Five $\mu$ l of the first PCR product and 10 pmoles/ $\mu \mathrm{l}$ of NG061 and NG063 primers were used for the second PCR. Amplifications conditions were $94^{\circ} \mathrm{C} 30 \mathrm{~s}, 55^{\circ} \mathrm{C} 30 \mathrm{~s}$, $72^{\circ} \mathrm{C} 30 \mathrm{~s}, 35$ cycles, with a final extension at $72^{\circ} \mathrm{C} 7 \mathrm{~min}$.

The amplification products of the first PCR round were $286 \mathrm{pb}$, and those of the second round were $271 \mathrm{bp}$. It was considered positive for the TTV control, human serum from a TTV positive patient, and negative, ultra pure sterile water, free from inhibitors or contaminants, which could avoid amplification of PCR products. Amplified products were separated by electrophoresis through a $2 \%$ agarose gel containing ethidium bromide, and visualized under UV light.

Sequencing. Sequence reactions were performed with the ABI Prism Big Dye Terminator Cycle sequencing Ready Reaction Kit (Applied Biosystems). Cycle sequencing was 
CATROXO, M.H.B.; NISHIYA, A.; SABINO, E. ; TEIXEIRA, P.S.; PETRELLA, S.; MILANELO, L.; VIEIRA, J.C.F.; DIAZ, R.S. Research of Torque teno virus (TTV) in serum and total blood of non-human primates and in chicken plasm (Gallus gallus domesticus) by the PCR-N22 region. Int. J. Morphol., 26(2):377-384, 2008.

carried out with an automatic DNA Sequencer (ABI Prism 377 Sequencer - Applied Biosystem). The primers used were NG061 and NG063 of the N22 region. Sequence edition was performed using the Sequencher program 4.0.5 (Gene Code Corporation). Sequence alignments were generated by the Bioedit Program (Hall, 1999). The phylogenetic analysis was performed using Philip version 3.5 c (Felsenstein, 1993).

Alignment with 3 edited sequences from the N22 region and series of standard sequences from different TTV genotypes from Gen Bank and from the literature were performed.

The sequence alignments were assessed using 1000 bootstrap replicates using SEQBOOT Program (Felsentein). Phylogenetic trees were constructed by the neighbor-joining method (Saitou \& Nei, 1997). The consense tree was calculed using the Consense Program and visualized in the Treview Program version 1.6.6 (win 32) (Roderic, 2001). The genotypes of the TTV had been determined by comparing the lined sequences (GenBank accession numbers EU919749-EU919752).

\section{RESULTS}

Non-human primates. Of 160 samples obtained from different species of new world non-human primates $(90$ serum and 70 whole blood) analyzed by the semi-nested PCR reaction for the $\mathrm{N} 22$ region only 4 samples of total blood were amplified, generating a band with a $271 \mathrm{pb}$ fragment in the second round. No serum sample was amplified.

TTV N22 DNA was detected in total blood from 3 (4\%) of 75 brown capuchin (Cebus apella) and from 1 (25\%) of 4 golden-headed-lion-tamarin (Leontopithecus chrysomelas). Among these $2(50 \%)$ were males and $2(50 \%)$ female, all adults (Table I).

Table I. Description of TTV positive samples by PCR of N22 region according to the species, gender, age and captivity origin. $\mathrm{M}=$ male, $\mathrm{F}=$ female.

\begin{tabular}{ccccc}
\hline - sample & Specie & Sex & Age & Origin \\
\hline 14 & Cebus apella & F & A & Parque Ecológico do Tietê, SP \\
17 & Cebus apella & F & A & Parque Ecológico do Tietê, SP \\
19 & Cebus apella & M & A & Parque Ecológico do Tietê, SP \\
45 & Leontopithecus chrysomelas & M & A & Zoo Sorocaba, SP \\
\hline
\end{tabular}

TGP 96

Mf-TTV3

Mf-TTV9

Pt-TTV6

Pt-TTV8-II

TTV SANBAN

So-TTV2

At-TTV3

TLMV-CBD203

TLMV-CBD231

TUSO 1

TA278

LC-TTV45

Ca-TTV14

Ca-TTV17

Ca-TTV19

CAU65414

M55918

TGP96

Mf-TTV3

Mf-TTV9

Pt-TTV 6

Pt-TTV8-II

TTV SANBAN

SO-TTV2

At-TTV3

TLMV-CBD203

TLMV-CBD231

TUS01

TA2 78

LC-TTV45

Ca-TTV14

Ca-TTV17

Ca-Trv19

CAV/U65414

M55918

\begin{tabular}{|c|}
\hline$\ldots \ldots l$ \\
\hline
\end{tabular}
QGESPYEQTC LPEDITRWYP M--YQYQTRE QNKILQTGPF TPYIQNLQSE NLCMYYKFRE TGNKVWIDPV TKKDTKFQPP Q--SLVLLEG QPLWLLLFGY TDWIKKFYA- DRNPGTTYRV IGNVVWTEPL TKKTCDYASQ ---AYNVIKD APLYLALFGY IDICSKLAK- DKSFYLSNRV TGNKIWCDSL TKADMKYTEG --RSKYLIEN LPLWAAVWGY LDYCTKTSG- DAAEHYNYRV

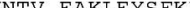
VGNHVWFOYN TKADTQLIVT GGSCKAHIED IPLWAAFYGY SDFIESELGP FVDAETVGLI REDQGWGNKV RLWTRECRTD IPEETLGIEN MPLYVLMNGY IDYVTNHST- --HSPLNWVV NRFAICDWPY KDQHGEQTTP LN-FDLEIKD APLWWCVTAA YDWAIRQGK- ---NPANWSE TGQSPYIEVL SQSDEKHWYP K--GSFQIKT LNTITSCGPG TVKLDNDKSC EAHFEYDFRF PEGQLYKTEL SETDKVHWHP K--YSMQTEQ LELISETGPA APKINNTKQI EAHLNYDEL KGNKIWFOYL SKKGTDYNEK --OCYCTLED MPLWAICFGY TDYVETOLGP NVDHETAGL Q ---MLWIDWL TKDDSQYSKT -OSKCLIEN LPLWASVYGY TEYCSKVTG- DTNIEHNCRC SGILPFPK-L EFRN--MWSL R--GAIPSPS LS-ITCC--- - - - - - - - - - - - -

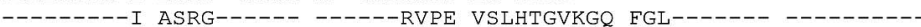
SGILPFPK-L EFRN--MWSL R--GAIPSPS LS-ITCCH--

ORDPDWYRWN YNHSIAVWLR -----ECSRS HAKICNCGOF RKHWFOECAG LEDRSSOASI QRDPDWYRWN YNHSIAVWLR -----ECSRS HAKICNCGQF RKHWFQECAG LEDRSTQASI

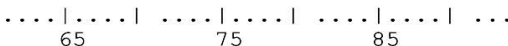

QWGGSPPKTV NVENPSHQNI FPIPRNEHET TSI TLLSPWTYPK LTN--KDLYG YVPLGDDECA GRH CVKCPYTVPQ LLSKTNATLG HVILSENEMR GLV TLISPYTSPM LFNPODPTKG FVPYSLNFGL GKM KFGGCPPPMA ATEDPCKOPT YOIPQT-- T TML CVICPYTKPP MYNKTNPMMG YVEYDRNEGD GKW SVFCPYTDPP MTNVIPVGKD WFIQNVEPGE NKY FVRSDYTWPR ADNIILAYSS Y--FADNVVK NKY KIGGCPPAME KLCDPSKQNK YPIPNTKLQT TSI KWGGSPAPME AITDPAEQEK FPSPSNQLQG LQI IMICPYTQPP MYDKNRPNWG YVVYDTNEGN GKM LIRSPETDPO LIVHTDPTKG FVPYSINFGN GKM TRSYTVP LLDHNNPLRG YVPYSFNFGN GKM ---------- ---------- ---------- --

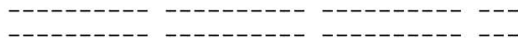

EEAILRPLRV QGKRAKRKLD YHYSQPTPNR KKV EEAILRPLRV QGKRAKRKLD YHYSOPTPNR KKA
Fig.1. Comparison between TTV N22 aminoacid sequences obtained from Brazilian non-human primates and sequences isolated from humans: TA278 (ABO17610) (Okamoto et al., 1999), TGP96 (AB041962) (Okamoto et al., 2000b), SANBAN (AB025946) (Hijikata et al., 1999), TLMV-CDB203 (AB026929) (Takahashi et al., 2000a), TLMV-CDB231 (AB026930) (Takahashi et al., 2000a), TUS01 (AB017613) (Okamoto et al., 1999), non-human primates: MfTTV3 (AB041958) (Okamoto et al., 2000b), MfTTV9 (AB041959) (Okamoto et al., 2000b), PtTTV6 (AB041957) (Okamoto et al., 2000b), Pt-TTV8II (AB041963) (Okamoto et al., 2000b), SoTTV2 (AB041960) (Okamoto et al., 2000b), AtTTV3 (AB041961) (Okamoto et al., 2000b) and chickens: CAV/U65414 (U65414) (Hamooleh et al., 1996), M55918 (M55918) (Noteborn et al., 1991). Isolates determined in this study are presented in bold. Dots indicate aminoacid identities, whereas dahes indicate gaps. 
CATROXO, M.H.B.; NISHIYA, A.; SABINO, E. ; TEIXEIRA, P.S.; PETRELLA, S.; MILANELO, L.; VIEIRA, J.C.F.; DIAZ, R.S. Research of Torque teno virus (TTV) in serum and total blood of non-human primates and in chicken plasm (Gallus gallus domesticus) by the PCR-N22 region. Int. J. Morphol., 26(2):377-384, 2008.

Phylogenetic analysis revealed that one sample showed similarity with one sequence of the cotton top tamarin (Saguinus oedipus) (So-TTV2) and with one of the douroucoulis (Aotes trivirgatus) (At-TTV3). Two samples showed similarity with a human Torque Teno Mini Virus (TLMV). The other sample clustered with one sequence of the chimpanzee (Pt-TTV6) and with the human TTV strain TA278 (Fig. 2).

Gallus gallus domesticus. The 117 plasm samples tested by the semi-nested PCR reaction for the N22 region were all negative.

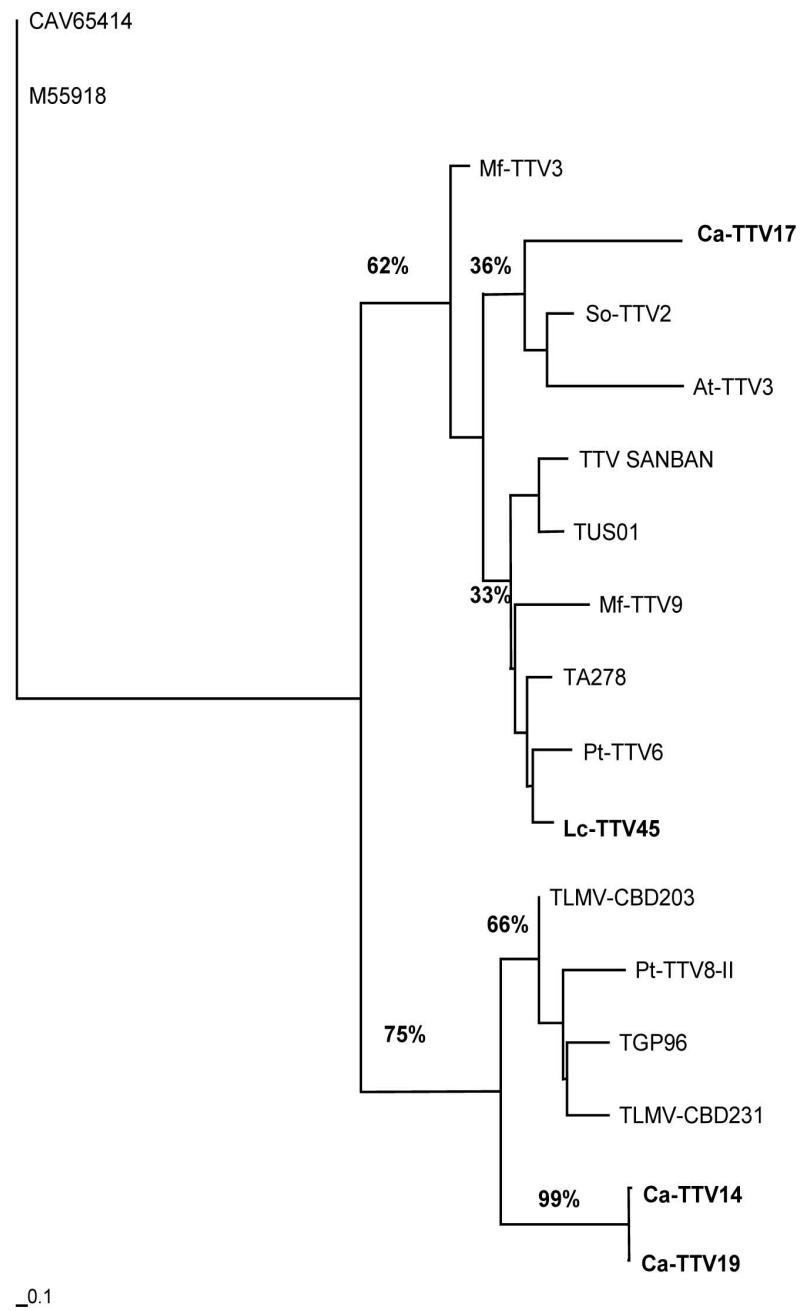

Fig. 2. Phylogenetic relationship between TTV-N22 aminoacid sequences obtained from Brazilian non-human primates and sequences isolated from humans, non-humans primates and chickens. The phylogenetic trees were constructed by the neighbourjoining method (Saitou \& Nei). Isolates determined in this study are presented in bold. The database-derived isolates and their accession numbers is given in the legend to Fig. 1.

\section{DISCUSSION}

The diagnostic of TTV infection is frequently realized by DNA amplification by PCR utilizing primers designed or by coding region of the ORF 1 (N22) or by non-coding region (UTR) of the viral genome (Ott et al., 2000).

The phylogenetic analysis of the TTV have been based on a small genome region that exhibits extensive sequence heterogeneity (Lemey et al.).

Our results obtained by the semi-nested PCR reaction for the N22 region revealed amplification in 4 (5.7\%) out of the 70 samples of total blood of new world non-human primates. However, no amplification was observed in 117 serum of the animals submitted to the same reaction.

On the contrary, other studies did not obtain positivity by the PCR of the N22 region, in samples of non-human primates of the old and new world (Abe et al.; Pujol et al.), not even in pig, cat and dog samples (Okamoto et al., 2002).

Studies in the literature have demonstrated variations in positivity percentage in samples of the old world nonhuman primates. Nopporpanth et al. detected 9 (13.4\%) of 67 gibbons, Thom et al. 1 (20\%) of 5 chimpanzees, Romeo et al. (2000) $2(25 \%)$ out of 8 naive chimpanzees, Verschoor et al. 60 (48.\%) out of 123 chimpanzees e 4 (66.\%) out of 6 pygmy chimpanzees, Barnett et al., 4 (80\%) of 5 chimpanzees of the Congo community and 3 (100\%) of 3 chimpanzees of the Sonso community of the Budongo Forest Reserve of Uganda.

Using specific primers for each species of chimpanzee, Okamoto et al. (2000a) detected 57\% in 49 out of 104 chimpanzees, but they did not obtain positivity in any sample that they have tested with new world non-human primates.

No other study in the literature has detected the presence of DNA TTV in new world non-human primates by the N22PCR.

Okamoto et al. (2000a) e Leary et al., however, detected DNA TTV in new world monkeys by PCR of the non-coding region (UTR), since the primers used in the N22-PCR only allow the amplification of a restricted number of TTV genotypes (Bendinelli et al., 2001; Vasconcelos et al., 2002).

In this study DNA TTV was detected in 3 samples of Cebus apella and in 1 sample of Leonthopithecus crysomelas. Abe et al. however, had detect DNA TTV in none of the 9 Cebus apella samples submitted to N22-PCR . 
CATROXO, M.H.B.; NISHIYA, A.; SABINO, E. ; TEIXEIRA, P.S.; PETRELLA, S.; MILANELO, L.; VIEIRA, J.C.F.; DIAZ, R.S. Research of Torque teno virus (TTV) in serum and total blood of non-human primates and in chicken plasm (Gallus gallus domesticus) by the PCR-N22 region. Int. J. Morphol., 26(2):377-384, 2008.

Cebus apella is the greatest specie, largely distributed in South America, present in all Amazon Forest, swamp, woodsy pasture, upland caatinga and Atlantic Rain Forest (Silva Júnior, 2002).

In our study one sequence of the Cebus apella clustered with one strain isolated from Saguinus oedipus (So-TTV2) and other with from Aotes trivirgatus (At-TTV3) of the Okamoto et al. (2000b).

Okamoto et al. (2000b) performed by cloned from UTRPCR products representing the full-length TTV genomes obtained from sera of humans and non-human primates that showed common genomic organization with two open reading frame (ORFs), designated ORF1 and ORF2 and their sequences were determined. In accordance with the author, these sequences bifurcated from the same branch harboring Japanese macaque TTV, reflecting a close relationship of these lower classes nonhuman primates TTVs.

Our results showed that one sequence clustered with a human TLMV (Torque Teno Mini Virus) sequence.

Furthemore, TTV and TLMV DNA sequences have been found in non-human primates and farm animals (Verschoor et al., 1999; Abe et al., 2000; Leary et al., 1999; Okamoto et al., 2000 a, b; Romeo et al., 2000).

TLMV is a unique virus with a smaller genome that may constitute a genetic evolutionary link between chicken anemia virus and TTV (Takahashi et al., 2000a).

In this study, 1 amplified sample (Cebus apella) was grouped with one strain of chimpanzee (Pt-TTV6) (Okamoto et al., 2000b) and with the TA278 human prototype strain.

A close proximity was observed, between the gibbon virus and those detected in Thai individuals, whereas that, chimpanzee strains were phylogenetically more remote (Noppornpanth et al.).

According to Verschoor et al. TTV from pygmy chimpanzees and the common chimpanzees closely to viruses from human TTV from the common chimpanzees subspecies Pan troglodytes verus and Pan troglodytes schwein furthii cluster together, suggesting an ancient host-pathogen relationship before sub speciation 1.6 million years ago and TTV of common and pygmy chimpanzees may have been acquired by these animals in different zoonotic events not longer than 2.5 million years ago.

Abe et al. reported one study that all TTV isolates obtained from simians (s-TTV) (old world non-human primates) were clearly distinct from TTV found in humans.
Inami et al. stated that a strain CH65-1 in ORF-1 region showed only $35 \%$ identity to the prototype TA278 human isolate at the amino acid level.

The results of our research showed that the sequence of DNA TTV obtained of the Cebus apella (Ca-TTV17) were close to human TTV of the genotype1.

In the same manner, gibbons sequences (Nopporpanth et al.) and in pygmy chimpanzees Okamoto et al. (2000a, b) were grouped in genotype 1 .

Verschoor et al. however, reported that TTV sequences from pigmy chimpanzees are closely related to viruses from human genotypes 2 and 3 , while that sequences obtained from common chimpanzees were genotypes 5 and 6 , the latter only at the protein level.

The phylogenetic analyses of the ORF1 nucleotide consensus sequences suggested that TTV recovered from two chimpanzees (CH1304 and $\mathrm{CH} 1545)$ represented two new genotypes (Romeo et al.).

Simian TTV (s-TTV) was further divided into three genotypes and showed type 1 as the major genotype (Abe et al.). In this study, it was not possible to detect DNA TTV by N22-PCR in 117 samples chicken plasma.

Only two reports refer to TTV research in chicken by PCR of the non-coding region (UTR). Thom et al. had investigated the presence of virus in 29 chicken samples, as well as the 20 samples from cows, 20 from sheep and 20 from goats, but all were PCR-UTR negative. Also, Leary et al. detected the virus in various farm animal species (chickens, pigs, cows and sheep) and verified that 19\% of chickens were positive by PCR-UTR, whose sequences clustered with human TTV. This different result are due to the fact of using primers deduced from a coding region sequence (N22).

The primers of the $\mathrm{N} 22$ region only allow the amplification of a restricted number of TTV genotypes (Bendinelli et al.; Vasconcelos et al.). Our results indicate that in spite of the TTV has been detected worldwide in wide scale in various animal species, in Brazil, however, their presence in new world non-human primates, in captivity and in chickens occurs in low number.

All the animals were clinically healthy, but very little is known, however, about the TTV infection of new world primates. The virus might have been transmitted from human handler to animals in the process of feeding or the wise handling the monkeys. 
CATROXO, M.H.B.; NISHIYA, A.; SABINO, E. ; TEIXEIRA, P.S.; PETRELLA, S.; MILANELO, L.; VIEIRA, J.C.F.; DIAZ, R.S. Research of Torque teno virus (TTV) in serum and total blood of non-human primates and in chicken plasm (Gallus gallus domesticus) by the PCR-N22 region. Int. J. Morphol., 26(2):377-384, 2008.

According Luo \& Zhang TTV is transmitted both by blood and enteric routs and perhaps in areas with inadequate hygienic standards, the virus is predominantly spread via the fecal-oral route.

The amino acid sequences reported in this study are the first obtained in Brazil from total blood of non-human primates naturally infected by TTV. The amino acid identity between human and non-human primates sequences in genotype 1 observed in this study supports the evidence that TTV is a zoonotic agent.

Further studies to evaluate the pathology, genetic diversity and host range, transmission, and persistence of TTV infection, in human and animal species will be conduced in order to outline considerable conclusions.

CATROXO, M.H.B.; NISHIYA, A.; SABINO, E. ; TEIXEIRA, P.S.; PETRELLA, S.; MILANELO, L.; VIEIRA, J.C.F.; DIAZ, R.S. Investigación de torque teno virus (TTV) en suero y sangre de primates no humanos brasileños y en plasma de pollo (Gallus gallus domesticus) por PCR en la Región N22. Int. J. Morphol., 26(2):377-384, 2008.

RESUMEN: Torque teno virus (TTV) es un virus de ADN recientemente descubierto que fue inicialmente aislado de un paciente japonés (iniciales TT) después de la transfusión de hepatitis de etiología desconocida. TTV es un virus de ADN circular recientemente clasificado junto con los torque teno minivirus, en un nuevo género llamado Anellovirus. La infección de TTV se ha detectado en una serie de primates no humanos, así como animales domésticos. El objetivo de este estudio fue buscar TTV en el suero y sangre total de monos de Brasil y en el plasma de pollos domésticos, por seminested PCR de la región de codificación (N22), seguido de una secuencia genómica y el análisis filogenético. Las muestras que no eran suero fueron amplificadas. TTV DNA se detectó en sangre total de $3(4 \%)$ de un total de 75 capuchinos de cabeza dura (Cebus apella) y de 1 (25\%) de un total de 4 tití- león de cabeza dorada (Leontopithecus chrysomelas). El análisis filogenético demostró que una muestra presentaba similitud con una secuencia de Saguinus Edipo (So-TTV2) y con una de Aotes trivirgatus (A-TTV3). Dos muestras mostraron similitud con un torque teno mini virus (TLMV) humano. La otra muestra agrupada con una secuencia de los chimpancés (PT-TTV6) y con el TTV humanos cepa TA278. El análisis de las muestras de plasma de pollo fueron negativas Las secuencias de aminoácidos que se reportan en este estudio son las primeras obtenidas en Brasil de sangre de primates no humanos infectados naturalmente por TTV.

PALABRAS CLAVE: Torque teno virus; Primates no humanos; Región de codificación; Secuencia de aminoácidos.

\section{REFERENCES}

Abe, K.; Inami, T.; Ishikawa, K.; Nakamura, S. \& Goto, S. TT virus infection in nonhuman primates and characterization of the viral genoma: identification of Simian TT virus isolates. J. Virol., 74(3):1549-53, 2000.

Al-Moslih, M. I.; Perkins, H. \& Hu, Y. W. Genetic relationship of Torque Teno virus (TTV) between humans and camels in United Arab Emirates (UAE). J. Med. Virol., 79:188-91, 2007.

Barnett, O. E.; Worobey, M.; Homes, E. C. \& Cooper, A. Detection of TT virus among chimpanzees in the wild using a noninvasive technique. J. Wildl. Dis., 40:230-7, 2004.

Bendinelli, M.; Pistello, M.; Maggi, F.; Fornai, C.; Freer, G. \& Vatteroni, M. L. Molecular properties, biology and clinical implications of TT virus, a recently identified widespread infectious agent of humans. Clin. Microbiol. Rev., 14(1):98-113, 2001.

Biagini, P. Presence of TT virus em French blood donors and intravenous drug users. J. Hepatol., 29:684-5, 1998.

Biagini, P.; Todd, D. \& Bendinelli, M. Anellovirus. In: Virus Taxonomy. Eighth Report of the International Committee on Taxonomy of Viruses. Fauquet, C. M.; Mayo, M. A.; Maniloff, J.; Desselberger, U. \& Ball, L. A. Eds. London, Academic Press, 2005. pp. 335-41.
Bigarré, L.; Beven, V.; Boissédon, C.; Grasland, B. O.; Rose, N. O.; Biagini, P. O. \& Jestin, A. Pig anelloviruses are highly prevalent in swine herds in France. J. Gen. Virol., 86:631-5, 2005.

Cong, M.; Nichols, B.; Dou, X.; Spelbring, J. E.; Krawczynski, K.; Fields, H. A. \& Khudyakov, Y. E. Related TT viruses in chimpanzees. Virology, 274:343-55, 2000.

Diniz-Mendes, L.; Devale, S. \& Niel, C. Genomic characterization of a Brazilian TT virus isolate closely related to SEN VirusF. Mem. Inst. Oswaldo Cruz., 99:301-6, 2004.

Felsenstein, J. PHILIP, version 3.5. Dept. of Genetics, University of Washington, Seattle, USA, 1993. (Distributed by the author at http://evolution.genetics.washington.edu/phylip.html).

Goto, K.; Sugiyama, K.; Ando, T.; Mizutani, F.; Terabe, K.; Tanaka, K.; Nishiyama, M. \& Wada, Y. Detection rates of TT virus DNA in serum of umbilical cord blood, breast milk and saliva. Tohoku. J. Exp. Med., 191(4):203-7, 2000.

Hall, T. A. BioEdit: a user-friendly biological sequence alignment editor and analysis program for Windows 95/98/NT. Nucl. Acids Symp. Ser., 41:95-8, 1999.

Hallett, R. L.; Clewley, J. P.; Bobet, F.; McKiernan, P. J. \& Teo, 
CATROXO, M.H.B.; NISHIYA, A.; SABINO, E. ; TEIXEIRA, P.S.; PETRELLA, S.; MILANELO, L.; VIEIRA, J.C.F.; DIAZ, R.S. Research of Torque teno virus (TTV) in serum and total blood of non-human primates and in chicken plasm (Gallus gallus domesticus) by the PCR-N22 region. Int. J. Morphol., 26(2):377-384, 2008.

C. G. Characterization fo a highly divergent TT virus genome. J. Gen. Virol., 81:2273-2279, 2000.

Hamooleh, G.; Cross, G. \& Dixon, R. J. DNA cloning and nucleotide sequencing of Australian chicken anaemia virus (U65414) (unpublished), 1996.

Hijikata, M.; Takahashi, K. \& Mishiro, S. Complete circular DNA genome of a TT virus variant (isolate name SANBAN) and 44 partial ORF2 sequences implicating a great degree of diversity beyond genotypes. Virology, 260:17-22, 1999.

Hino, S. TTV, a new human virus with single stranded circular DNA genome. Rev. Med. Virol., 12(3):151-8, 2002.

Inami, T.; Obara, T.; Moriyama, M.; Arakawa, Y. \& Abe, K. Fulllenght nucleotide sequence of a simian TT virus isolate obtained from a chimpanzee: evidence for a new TT viruslike species. Virology, 277:330-5, 2000.

Itoh, J.; Takahashi, M.; Fukuda, M.; Shibayama, T.; Ishikawa, T.; Tsuda, F.; Tanaka, T.; Nishizawa, T. \& Okamot, H. Visualization of TT virus particles recovered from the sera and feces of infected humans. Bioch. Bioph. Res. Comm., 279:718-24, 2000 .

Khudyakov, Y. E.; Cong, M. E.; Nichols, B.; Reed, D.; Dou, X. G.; Viazov, S. O.; Chang, J.; Fried, M. W.; Roggendorf, M. \& Fields, H. A. Sequence heterogeneity of TT virus and closely related viruses. J. Virol., 74(7):2990-3000, 2000.

Leary, T. P.; Erker, J. C.; Chalmers, M. L.; Desai, S. M. \& Mushahwar, I. K. Improved detection systems for TT virus reveal high prevalence in humans, non-humans primates and farm animals. J. Gen. Virol., 80:2115-20, 1999.

Lemey, P.; Salemi, M.; Bassit, L. \& Vandamme, A-M. Phylogenetic classification of TT virus groups based on the N22 region is unreliable. Virus Res., 85(4):47-59, 2002.

Luo, K. \& Zhang, L. Enteric transmission of transfusiontransmitted virus. Chin. Med. J., 114:1201-4, 2001.

Mac Donald, D. M.; Scott, G. R.; Clutterbuck, D. \& Simmonds, P. Infrequent detection of TT virus infection in intravenous drug users, prostitutes, and homosexual men. J. Infect. Dis., 179:686-9, 1999

Martelli, F.; Caprioli, A.; Di Bartolo, I.; Cibin, V.; Pezzotti, G. Ruggeri, F. M. \& Ostanello, F. Detection of swine Torque teno virus in Italian pig herds. J. Vet. Med., B53:234-8, 2006.

Martinez, L.; Kekarainen, T.; Sibila, M.; Ruiz-Fons, F.; Vidal, D. $\&$ Segales, J. Torque teno virus (TTV) is highly prevalent in the European wild boar (Sus scrofa). Vet. Microbiol., 118(34):223-9, 2006.
Mc Keown, N. E.; Fenaux, M.; Halbur, P. G. \& Meng, X. J. Molecular characterization of porcine TT virus, and orphan virus, in pigs from six different countries. Vet. Microbiol., 104:113-7, 2004.

Miyata, H.; Hsunoda, H.; Kazi, A.; Yamada, A.; Khan, M. A.; Muakami, J.; Kamahora, T.; Shiraki, K. \& Hino, S Identification of a novel GC-rich 113 nucleotide region to complete the circular single-stranded DNA genome of TT virus, the first human circovirus. J. Virol., 73:3582-6, 1999.

Mushahwar, I. K.; Erker, J. C.; Murchoff, A. S.; Leary, T. P.; Simons, J. N.; Birkenmeyer, L. G.; Chalmers, M. L.; PilotMatias, T. J. \& Desai, S. M. Molecular and biophysical characterization of TT virus: evidence for a new virus family infecting humans. Proc. Natl. Acad. Sci., 96:3177$82,1999$.

Niel, C.; Diniz-Mendes, L. \& Devalle, S. Rolling-circle amplification of Torque teno virus (TTV) complete genomes from human and swine sera and identification of a novel swine TTV genogroup. J. Gen. Virol., 86:1343-7, 2005.

Nishizawa, T.; Okamoto, H.; Konishi, K.; Yoshizawa, H.; Miyakawa, Y. \& Mayumi, M. A novel DNA virus (TTV) associated with elevated transaminase levels in posttransfusion hepatitis of unknown etiology. Biochem. Biophys. Res. Commun., 241:92-7, 1997.

Noppornpanth, S.; Chingai, T.; Ratanakorn, P. \& Poovorawan, Y. TT virus infection in gibbons. J. Vet. Med. Sci., 63:6636, 2001

Noteborn, M. H.; de Boer, G. F.; van Roozelaar, D. J.; Karreman, C.; Kranenburg, O.; Vos, J. G.; Jeurissen, S. H.; Hoeben, R. C.; Zantema, A.; Koch, G.; van Ormondt, H. \& van der Eb, A. J. Characterization of cloned chicken anemia virus DNA that contains all elements for the infectious replication cycle. J. Virol., 65:3131-9, 1991.

Okamoto, H.; Nishizawa; Ukita, M.; Takahashi, M.; Fukuda, M.; Lizuka, H.; Miyakawa, Y. \& Mayumi, M. The entire nucleotide sequence of a TT virus isolate from the United States (TUS 01): comparison with reported isolates and phylogenetic analysis. Virology., 259:437-48, 1999.

Okamoto, H.; Fukuda, M; Tawara, A.; Nishizawa, T.; Itoh, Y.; Ayasaka, I.; Tsuda, F.; Tanaka, T.; Miyakawa, Y. \& Mayumi, M. Species-specific TT virus and cross-species infection in nonhuman primates. J. Virol., 74(3):1132-9, 2000a.

Okamoto, H.; Nishizawa, T.; Tawara, A.; Peng, Y.; Takahashi, M.; Kishimoto, J.; Tanaka, T.; Miyakawa, Y. \& Mayumi, M. Species-specific TT viruses in humans and nonhuman primates and their phylogenetic relatedness. Virology, 277(2):368-78, $2000 b$. 
CATROXO, M.H.B.; NISHIYA, A.; SABINO, E.; TEIXEIRA, P.S.; PETRELLA, S.; MILANELO, L.; VIEIRA, J.C.F.; DIAZ, R.S. Research of Torque teno virus (TTV) in serum and total blood of non-human primates and in chicken plasm (Gallus gallus domesticus) by the PCR-N22 region. Int. J. Morphol., 26(2):377-384, 2008.

Okamoto, H. \& Mayumi, M. TT virus: virological and genomic characteristics and disease associations. J. Gastroenterol, 36:519-29, 2001.

Okamoto, H.; Nishizawa, T.; Takahashi, M.; Tawara, A.; Peng, Y.; Kishimoto, J. \& Wang, Y. Genomic and evolutionary characterization of TT virus (TTV) in Tupaias and comparison with species-specific TTVs in humans and nonhuman primates. J. Gen. Virol., 82:2041-50, 2001 a.

OKamoto, H.; Takahashi, M.; Nishizawa, T.; Tawara, A.; Fukai, K.; Muramatsu, U.; Naito, Y. \& Yoshikawa, A. Genomic characterization of TT viruses (TTVs) in pigs, cats and dogs and their relatedness with species-specific TTVs in primates and tupaias. J. Gen. Virol., 83:1291-7, 2002.

Osiowy, C. \& Sauder, C. Detection of TT virus in human hair and skin. Hepatol. Res., 16:155-62, 2000.

Ott, C.; Duret, L.; Chemin, I.; Trépo, C.; Mandrand, B. \& Komurian-Pradel, F. Use of a TT virus ORF 1 recombinant protein to detect anti -TT virus antibodies in human sera. J. Gen. Virol. 81:2949-58, 2000.

Peng, Y. H.; Nishizawa, T.; Takahashi, M.; Ishikawa, T.; Yoshikawa, A. \& Okamoto, H. Analysis fo the entire genomes of thirteen TT virus variants classifiable into the fourth and fifth genetic groups, isolated from viremic infants. Arch. Virol., 147:21-41, 2002.

Pujol, F. H.; Mejías, E.; Loreiro, C. L.; Ludert, J. E.; Liprandi, F. \& Pernalete, J. M. Infection with transfusion-transmitted virus (TTV) in humans and other primates in Venezuela. Ann. Trop. Med. Parasitol., 99:173-80, 2005.

Roderic, D. M. TREEVIEW. Glasgow, Scotland: University of Glasgow, (Distributed by the author at http:// taxonomy.zoology.gla.ac.uk/rod/treeview.htm), 2001.

Romeo, R.; Hegerich, P.; Emerson, S. U.; Colombo, M.; Purcell, R. H. \& Bukh, J. High prevalence of TT virus (TTV) in naive chimpanzees and in hepatitis $\mathrm{C}$ virus-infected humans: frequent mixed infections and identification of new TTV genotypes in chimpanzees. J. Gen. Virol., 81:1001-7, 2000.

Saback, F. L.; Gomes, S. A. S.; Paula, V. S.; Da Silva, R. R. S.; Lewis-Ximenez, L. L. \& Niel, C. Age specific prevalence and transmission of TT virus. J. Med. Virol., 59:318-22, 1999.

Saitou, N. \& Nei, M. The neighbor-joining method: a new method for reconstructing phylogenetic trees. Mol. Biol. Evol., 4:406-25, 1997.

Silva Júnior, J. S. Taxonomy of capuchin monkeys, Cebus Erxleben. Neotrop. Primates, 2(1):29, 2002.
Takahashi, K.; Iwasa, Y.; Hijikata, M.; Mishiro, S. Identification of a new human DNA virus (TTV-like mini virus, TLMV) intermediately related to TT virus and chicken anemia virus. Arch. Virol., 145:979-93, 2000a.

Takahashi, K.; Hijikata, M.; Samokhvalov, E. I. \& Mishiro, S. Full or near full lenght nucleotide sequences of TT virus variants (types SANBAN and YONBAN) and TT viruslike mini virus. Intervirology, 43(2):119-23, $2000 \mathrm{~b}$.

Tawara, A.; Akahane, Y.; Takahashi, M.; Nishizawa, T.; Ishikawa, T. \& Okamoto, H. Transmission of human TT virus of genotype 1a to chimpanzees with fecal supernatant or serum from patients with acute TTV infection. Biochem. Biophys. Res .Commun., 278(2):470-6, 2000.

Thom, K.; Morrison, C.; Lewis, J. C. M. \& Simmonds, P. Distribution of TT virus (TTV), TTV-like minivirus, and related viruses in humans and nonhuman primates. Virology., 306:324-33, 2003.

Ukita, M.; Okamoto, H.; Nishizawa, T.; Tawara, A.; Takahashi, M.; lizuka, H.; Miyakawa, Y. \& Mayumi, M. The entire nucleotide sequences of two distinct TT virus (TTV) isolates (TJN01 and TJN02) remotely related to the original TTV isolates. Arch. Virol., 145:1543-59, 2000.

Vasconcelos, H. C.; Cataldo, M. \& Niel, C. Mixed infections of adults and children with multiple TTV-like mini virus isolates. J. Med. Virol., 68(2):291-8, 2002.

Verschoor, E. J.; Langenhuijzen, S. \& Heeney, J. L. TT viruses (TTV) of non-human primates and their relationship to the human TTV genotypes. J. Gen. Virol., 80:2491-9, 1999.

Yokoyama, H.; Yassuda, J.; Okamoto, H. \& Iwakura, Y. Pathological changes of renal epithelial cells in mice transgenic for the TT virus ORF1 gene. J. Gen. Virol., 83(1):141-50, 2002.

Correspondence to:

Prof. Dr. Márcia Catroxo

Electron Microscopy Laboratory

Biological Institute of São Paulo

Avenida Conselheiro Rodrigues Alves, 1252

CEP: 04014-002

Vila Mariana, São Paulo, SP,

BRAZIL

Email: catroxo@biologico.sp.gov.br

Received: 24-01-2008

Accepted: 14-03-2008 